\title{
Forensic Aspects of Probable Life-Threatening Complications of Closed Chest Cardiopulmonary Resuscitation in Non-Traumatic Patients
}

\author{
Sahar Mohamed Moustafa ${ }^{1}$ \\ ${ }^{1}$ Department of Forensic Medicine and Clinical Toxicology, Faculty of Medicine- Suez Canal University, Egypt.
}

\begin{abstract}
Cardiopulmonary resuscitation (CPR) is a life-saving procedure that can also cause many life-threatening injuries to patients. The complications that can arise from the application of CPR are confronted by the existing legal system as a medical error and since forensic pathologists often encounter various types of CPR-related injuries during autopsies, they must be able to distinguish between CPR-related injuries and those caused by other factors. The aim of the present study was to analyze the findings of autopsy reports of patients who received CPR to determine the frequency of its related life-threatening injuries and to determine the possible factors that affect and increase the risk of these injuries. The study included 58 nontraumatic death cases that had undergone CPR and CPR-related injuries were determined based on X ray/ CT interpretation reports. The results concluded that the advanced life support was provided in the vast majority of cases $(70.7 \%)$. The mean duration of CPR provided was $(22.0 \pm 12.35 \& 21.5 \pm 13.56$ min.) in males and females respectively and defibrillation procedure took place in $79.3 \%$ of cases. The most common complications detected were the thoracic cage complications where the costal injuries were the most frequent complications in $48.4 \%$ of cases, mid-clavicular rib fracture was the most frequent one and $66.7 \%$ of sternal fractures were detected at the level of the third rib. Males were more susceptible to rib and sternal fractures than females. The factors of age, gender and CPR duration were found to have an effect on the increased risk of life-threatening injuries. The risk of injury increases especially when the compression depth exceeded $6 \mathrm{~cm}$. and CPR duration exceeds $30 \mathrm{~min}$. The present study concluded that CPR complications may decrease the patient's chance of survival and can cause death by itself. The present study recommend detailed post-mortem studies on CPR related life-threatening injuries on a trial of their prevention.
\end{abstract}

\begin{tabular}{l|l} 
Keywords & Cardiopulmonary resuscitation, non-traumatic cases and life-threatening complications.
\end{tabular}

Introduction

udden death from cardiac arrest is a major medical issue and one of the biggest people's fears. The $\checkmark$ chain of Basic Life Support is the only way to improve the survival which includes early access and on time implementation of cardiopulmonary resuscitation (CPR) (Deliligka et al., 2016).

CPR is an emergency procedure involving external chest compression and artificial ventilation that aims to restore oxygenated blood flow to the brain and heart in individuals with cardiac arrest (Olds et al., 2015) while it can also cause many life-threatening injuries to patients (Hashimoto et al., 2007).

CPR contains a significant violation risk with forensic relevance, for the patient and the physician (Buschmann and Tsokos, 2009) and CPR-related injuries are confronted by the existing legal system as a medical error, as in the performance of any medical procedure with adverse outcome (Deliligka et al., 2016).

CPR complications can cause death by itself, or it can be misinterpreted to be a blunt trauma as a cause of death, and also it can be evaluated as medical malpractice (Özer et al., 2010). Since forensic pathologists often encounter various types of CPR-related injuries during autopsies, they must be able to distinguish between them and those caused by other factors (Hashimoto et al., 2007).

Although there have been many studies focused on the incidence of or factors related to complications of CPR (Rilana Baumeister et al., 2015) a little attention has been paid to this potential problem (Hokea and Chamberlaina, 2004) and CPR related life-threatening injuries created a need for detailed post-mortem studies for their prevention (Kaldirim et al., 2016). 
Awareness of those complications is vital in autopsy investigations as in fatal traumatic cases they may be interpreted as additional trauma signs and in fatal non-traumatic cases autopsy may be misinterpreted by those complications findings and suggesting traumatic cause of death. Thus, information about possible CPR complications are crucial for forensic medical specialists to distinguish them from actual trauma symptoms and important for physicians who perform resuscitation to be aware of those complications in terms of comprehension and a reduction in medical errors (Beydilli et al., 2015).

The aim of the present study was to analyze the findings of autopsy reports of individuals who received CPR to determine the frequency of CPR related lifethreatening injuries and to determine the possible factors that affect and increase the risk of those injuries.

\section{Subjects and methods Subjects}

Autopsy reports from complicated cases received CPR between 2014 and 2017 in the mortuary in Council of Forensic Medicine in Riyadh of Saudi Arabia were analyzed retrospectively after an ethical approval obtained from the scientific committee. The study included 58 non-traumatic death cases that had undergone CPR measures according to American Heart Association guideline and subjected for evaluation from hospital files and emergency team. Autopsies were performed when the cause of death was uncertain. The socio-demographic characteristics, the definitive cause of cardiac arrest, suggested cause of death and data about CPR provided (basic life support/advanced life support, duration of CPR, defibrillation and specification of persons performing chest compressions) were extracted from the medical records. The inclusion criteria involved the fatal cases after cardiac arrest suspected to CPR without any history or evidence of trauma prior to CPR. Cases below 18 years or with thoracic and abdominal trauma during attempted resuscitation were excluded from the study.

\section{Methods}

Life-threatening injuries were evaluated using the guideline based on the Abbreviated Injury Scale (AIS). The cases were investigated through post-mortem chest $\mathrm{X}$-ray imaging and/or chest/upper abdomen computed tomography (CT) and the complications were determined based on $\mathrm{X}$ - ray/CT interpretation reports which were conducted by hospital's radiologist. The presence of a probable relationship between the injuries and factors such as age, gender, CPR duration and depth of chest compression was examined. Data from each autopsy was recorded according to a standardized study protocol for external and internal injuries.

\section{Statistical analysis}

The SPSS software was used. Mean and percentages for variables were calculated and $\chi^{2}$ test used for comparisons of categorical variables and t-test for means of data with normal distribution while $\mathrm{P}$ values $<0.05$ were considered to indicate statistical significance. Odds ratio and 95\% Confidence interval were calculated for evaluation by logistic regression analysis of factors affecting the CPR related life-threatening injuries.

\section{Results}

Among the autopsy cases who underwent CPR and whose autopsy detected resuscitation complications, all CPR procedure were took place inside the hospital by trained physicians and there were 58 cases, 38 of them (65.5\%) were males and 20 (34.5\%) were females, their mean age was $48.2 \pm 15.4$ (mean \pm SD) and mean body mass index (BMI) was $26.7 \pm 5.14$. Table (1) shows that among the autopsy cases, the most frequent cause of death was found to be related to cardiovascular disease (55.2\% of cases) followed by pathological brain hemorrhage in $19 \%$ of cases.

Table (2) shows the specifications regarding CPR provided to the study group, in which basic life support alone was performed in 17 (29.3\%) cases and advanced life support was provided in the vast majority of cases (70.7\%). The mean duration of CPR provided to individuals was $22.0 \pm 12.35 \mathrm{~min}$. in males while it was $21.5 \pm 13.56 \mathrm{~min}$. in females and defibrillation takes place in 46 (79.3\%) of cases. A positive association was detected between mean chest compression depth and the CPR-related injuries, as when the compression depth increases the risk of injury increases especially when the chest compression depth exceeded $6 \mathrm{~cm}$. The differences between males and females were not statistically significant regarding CPR type, depth of chest compression and duration of CPR or receiving defibrillation procedure.

Table (3) shows that the most common complications detected were the thoracic cage complications which showed highly significant difference between males and females followed by lung complications while the least common complications were the upper airway complications.

Table (4) shows that males were more susceptible to complications related to chest compression. Costal injuries were the most frequent complication and the most common injury was a single rib fracture in the anterior part of the thoracic cage. Lung contusion, pneumothorax, haemothorax, ventricular rupture and liver laceration showed statistically nonsignificant difference between males and females while thoracic cage fractures showed highly significant difference between males and females. Figure (1) shows pneumothorax after external CPR.

Table (5) shows that among the costal fractures after CPR, the mid-clavicular rib fractures were the most frequent fractures with a highly significant difference between males and females followed by the parasternal rib fractures, while $(80.6 \%)$ of the rib fractures were at the left side of the thorax as illustrated in Figure (2) which showed fracture of the third rib after external CPR.

Table (6) shows that males were more susceptible to sternal fracture and $66.7 \%$ of sternal fractures were detected at the level of the third rib as illustrated in Figure (3) with a highly significant difference between males and females. 
Table (7) shows that the factors of age, gender and CPR duration were founed to have an effect on the increased risk of life-threatening injuries and they are positively correlated with the occurrence of them especially the CPR period as when application time increases the risk of injury increases.

Table (1): Distribution of cause of death in the present study population.

\begin{tabular}{|c|c|c|}
\hline Cause of death & No. & $\mathbf{\%}$ \\
\hline Cardiovascular disease & 32 & 55.2 \\
\hline Pathological brain hemorrhage & 11 & 19 \\
\hline Cancer & 7 & 12 \\
\hline Others & 8 & 13.8 \\
\hline
\end{tabular}

Table (2): CPR specifications in the present study population.

\begin{tabular}{|c|c|c|c|c|}
\hline Parameter & Male & Female & percentage & P \\
\hline Type of provided CPR: & 10 & 7 & 29.3 & 0.105 \\
Basic life support (BLS) & 28 & 13 & 70.7 & 0.699 \\
Advanced life support (ALS) & & & & \\
\hline CPR duration (minutes) & $22.0 \pm 12.35$ & $21.5 \pm 13.56$ & - & 0.799 \\
(mean + SD) & & & & \\
\hline Mean chest compression depth: & - & - & - & - \\
\hline < 5 cm. & 9 & 7 & 27.6 & 0.25 \\
5-6 cm. & 29 & 13 & 72.4 & 0.34 \\
> 6 cm. & 31 & 15 & 79.3 & 0.106 \\
\hline Defibrillation & 7 & 5 & 20.7 & 0.106 \\
Yes & & & & \\
\hline
\end{tabular}

Table (3): CPR complications related to chest compression.

\begin{tabular}{|c|c|c|c|c|}
\hline \multirow[t]{2}{*}{ Complication } & \multirow[t]{2}{*}{ No. (58) } & \multicolumn{2}{|c|}{ Gender } & \multirow[t]{2}{*}{$\mathbf{P}$} \\
\hline & & Male (38) & Female (20) & \\
\hline Upper airway & 2 & 2 & - & - \\
\hline Thoracic cage & 43 & 28 & 15 & $0.005 *$ \\
\hline Lung & 7 & 4 & 3 & 0.963 \\
\hline Heart & 3 & 2 & 1 & 0.876 \\
\hline Abdomen & 3 & 2 & 1 & 0.876 \\
\hline
\end{tabular}

*Statistically significant

Table (4): Distribution of injuries due to cardiopulmonary resuscitation.

\begin{tabular}{|c|c|c|c|c|}
\hline \multirow{2}{*}{ Injuries } & \multicolumn{2}{|c|}{ Gender } & \multirow{2}{*}{ Percentage } & \multirow{2}{*}{ P } \\
\cline { 2 - 3 } & Male & Female & & \\
\hline Esophageal bleeding & 2 & - & 3.4 & - \\
\hline Costal fracture & 16 & 12 & 48.4 & $0.005^{*}$ \\
\hline Sternal fracture & 4 & 1 & 8.6 & $0.005^{*}$ \\
\hline Both costal and sternal fracture & 3 & 1 & 6.8 & $0.05^{*}$ \\
\hline Pneumothorax & 3 & - & 5.2 & - \\
\hline Haemothorax & 2 & 1 & 5.2 & 0.977 \\
\hline Lung contusion & 4 & 3 & 12 & 0.766 \\
\hline Ventricular rupture & 2 & 1 & 5.2 & 0.977 \\
\hline Liver laceration & 2 & 1 & 5.2 & 0.977 \\
\hline
\end{tabular}

*Statistically significant 
Table (5): Distribution of costal fractures according to their location in the studied population.

\begin{tabular}{|c|c|c|c|c|c|c|}
\hline \multirow{2}{*}{ Fracture location } & \multicolumn{2}{|c|}{ Location } & \multicolumn{2}{|c|}{ Gender } & \multirow{2}{*}{ Percentage } & \multirow{2}{*}{ P } \\
\cline { 2 - 5 } & Rt & Lf & Male & Female & & \\
\hline Parasternal & 2 & 8 & 6 & 4 & $31.2 \%$ & $0.05^{*}$ \\
\hline Midclavicular & 4 & 14 & 11 & 7 & $56.3 \%$ & $0.05^{*}$ \\
\hline Axillar & 1 & 3 & 2 & 2 & $12.5 \%$ & - \\
\hline
\end{tabular}

*Statistically significant

Table (6): Distribution of sternal fractures according to its location in studied population.

\begin{tabular}{|l|c|c|c|c|}
\hline \multirow{2}{*}{ Fracture location } & \multicolumn{2}{|c|}{ Gender } & \multirow{2}{*}{ Percentage } & \multirow{2}{*}{ P } \\
\cline { 2 - 4 } & Male & Female & & \\
\hline Level of 2nd rib & - & - & - & - \\
\hline Level of 2nd-3rd intercostal space & - & - & - & - \\
\hline Level of 3rd rib & 5 & 1 & 66.7 & 0.01 \\
\hline Level of 3rd-4th intercostal space & - & - & - & - \\
\hline Level of 4th rib & 2 & 1 & 33.3 & 0.987 \\
\hline
\end{tabular}

Table (7): The evaluation by logistic regression analysis of factors affecting life-threatening injuries.

\begin{tabular}{|c|c|c|}
\hline Variable & Odds ratio & 95\% Confidence interval \\
\hline Age & 1.077 & $1.01-1.21$ \\
\hline \multirow[t]{2}{*}{ Gender } & Female & - \\
\hline & Male & $1.13-6.23$ \\
\hline \multirow[t]{2}{*}{ CPR Duration } & $\leq \mathbf{3 0}$ min. 1 & - \\
\hline & 31-60 min. 0.95 & $0.34-3.23$ \\
\hline
\end{tabular}

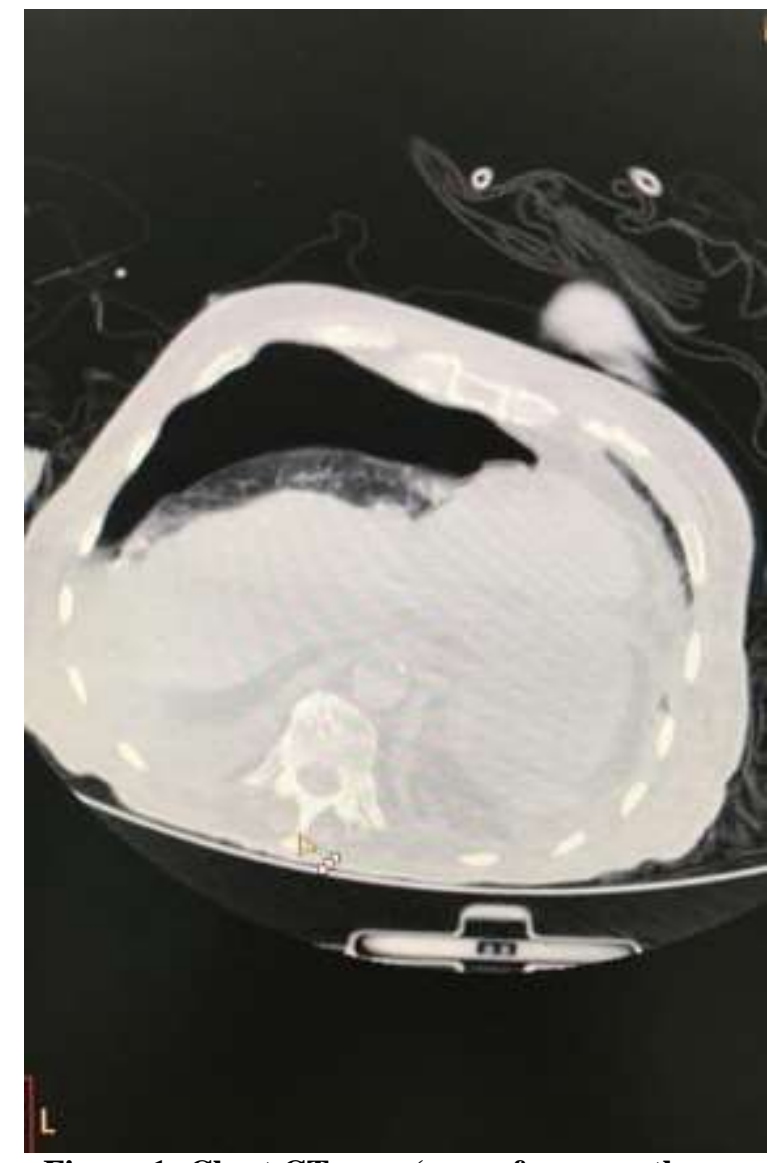

Figure 1: Chest CT scan (case of pneumothorax after external CPR).

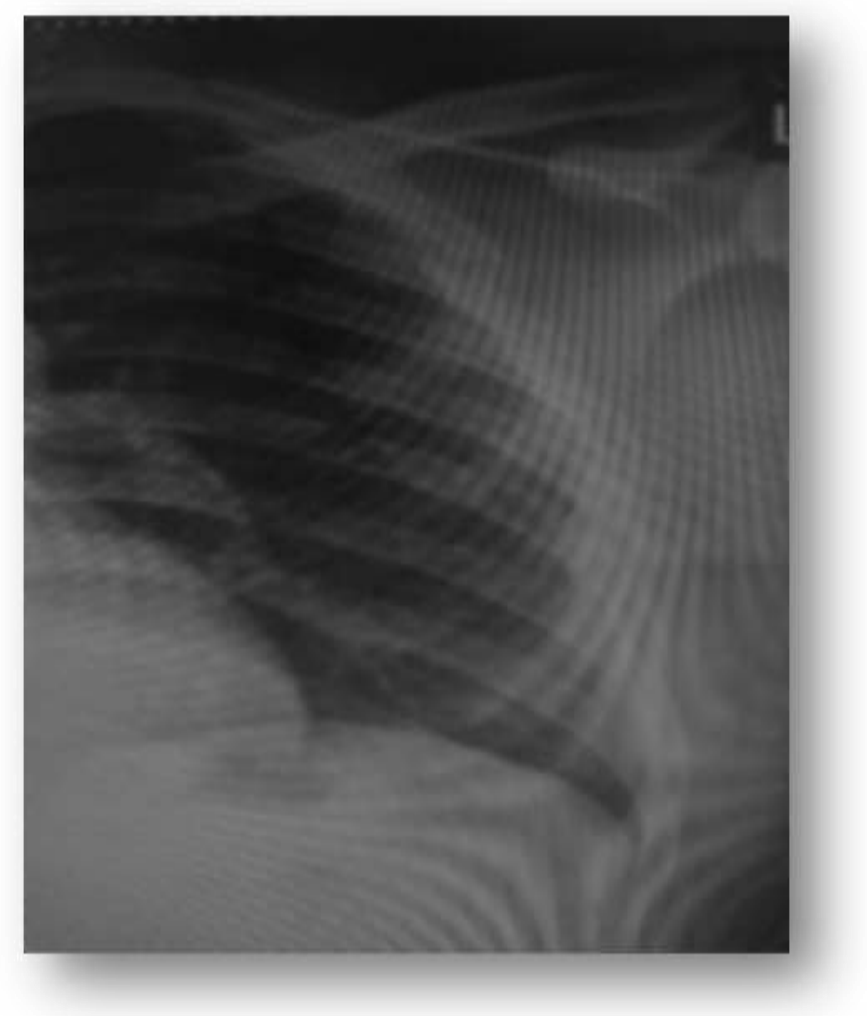

Figure 2: Chest X-ray (case of third rib fracture after external CPR) 


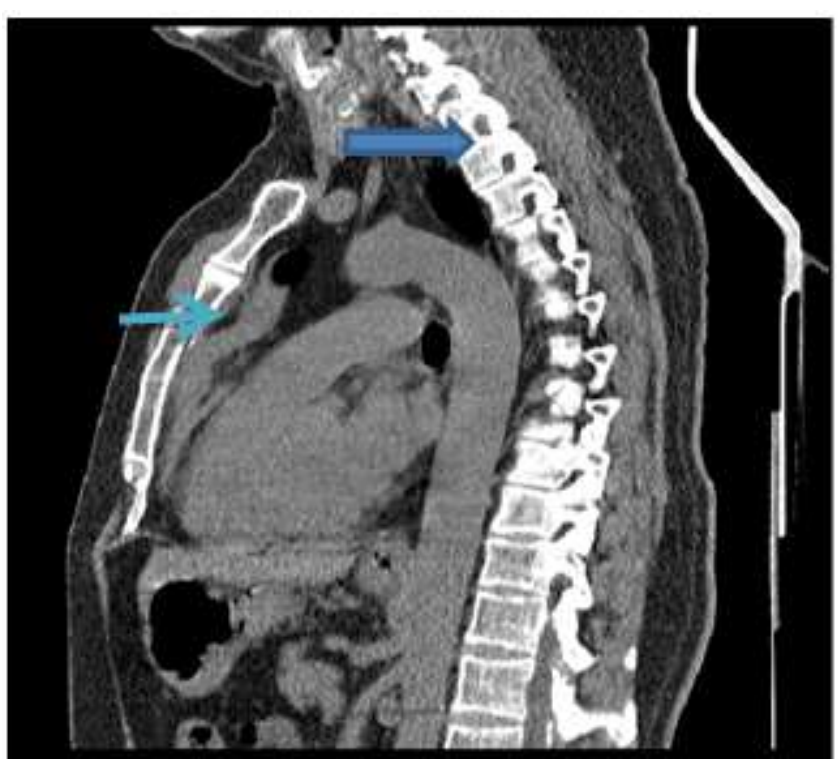

Figure 3: Chest CT scan (case of sternal fracture after external CPR)

\section{Discussion}

There were many changes in CPR international guidelines within the last decades, but effective chest compression remains the cornerstone of successful CPR (Travers et al., 2010).

If closed-chest compressions are not performed properly during basic life support measures, they can be traumatic where published values for the incidences of resuscitative injuries range from $21 \%$ to more than $65 \%$ (Sommers 1991).

In general, autopsy is the most sensitive method for detecting complications of resuscitation (Kim et al., 2013).

The present results revealed that the most common complications detected after CPR procedure were the thoracic complications in $86.2 \%$ of cases, among the thoracic complications the costal injuries were the most frequent complications (48.4\%) and sternal fracture (8.6\%). The present results are in accordance with the results revealed that prevalence of rib and/or sternum fractures after resuscitation varies between $16 \%$ and 75\% (Machii et al., 2000).

In patients with unsuccessful CPR after cardiac arrest, rib fractures were more frequent after mechanical CPR (Smekal et al., 2014).

CPR-associated injuries were found in 93.7\% of cases and the majority of injuries were skeletal chest fractures (rib fractures in $73.7 \%$, sternal fractures in $66.3 \%)$

(Rudinskáa 2016).The present study concluded that among the costal fractures the midclavicular rib fractures were the most frequent fractures (with highly significant difference between males and females) in $58 \%$ of fracture cases followed by the parasternal fractures in $32.2 \%$ and $80.6 \%$ of the rib fractures were at the left side of the thorax which are in accordance with Özer et al. (2010) results, they revealed that sixty-nine percent of the rib fractures were at the left side of the thorax, seventy-one percent of the fractures were found at the midclavicular line, $14 \%$ at the parasternal and $12 \%$ were found at the axillary line.

Ryan et al. (2003) results concluded that rib fractures due to resuscitation are mostly located between $3^{\text {rd }}$ and $8^{\text {th }}$ ribs and are more common at the left side and at the region between the parasternal and axillary line. The present results were in difference with the previous results which concluded that rib fractures were found in $29 \%$ and sternal fracture in 14\% (Black et al., 2004).

The present results concluded that $66.7 \%$ of sternal fractures were detected at the levels of the third rib which in accordance with Lederer et al. (2004) results which concluded that sternal fractures predominantly occurred in its lower third. Sternal fractures were found in 29 (4.8\%) of CPR-receiving cases (Özer et al., 2010). The present results revealed that males were more susceptible to rib and sternal fractures and these results are in contrast with Kim et al. (2011) results which concluded that females were more susceptible to rib and sternal fractures. More females sustained rib fractures than males (37\% versus $26 \%$ ). There was no significant gender difference for sternal fracture (females $17 \%$, males 12\%) (Black et al., 2004).

The present results proved a positive relationship between age and gender and injuries caused by chest compressions, rib fractures in particular may be more frequent in elderly patients receiving CPR.

Black et al. (2004) reported that the incidence of rib fractures increased with age. These results are in accordance with Hellevuo et al. (2013) results which reported a relationship between the depth of CPR and the injuries in male patients, but not female patients.

Boz et al. (2008) reported that the relationship between gender and injuries was not statistically significant. Kim et al. (2013) found that female gender is a risk factor for rib fractures. The present results are in 
contrast with Kaldirım et al. (2016) results which noted that there was no relationship between age and gender with chest injury. In the present study, the CPR period was found to be positively correlated with the occurrence of injuries.

The results are in accordance with Guzel et al. (2013) results which reported that the duration of chest compression application is known to be a significant factor in terms of life threatening injuries.

Kaldirim et al. (2016) reported that the risk of injury was found to be highest in the group where CPR had been applied for 60 min or more. The current study concluded that when the compression depth increases the risk of injury increases especially when the compression depth exceeded $6 \mathrm{~cm}$. This in accordance with a study concluded that CPR-related injuries were associated with deeper mean compression depths of $<5,5-6$ and $>6 \mathrm{~cm}$., the percentages of injuries were $28 \%, 27 \%$ and $49 \%$ respectively (Hellevuo et al., 2013).

\section{Conclusion and recommendations}

According to the present study outcomes, serious complications of CPR in patients after unsuccessful CPR may contribute to death or may be potentially lethal. Thoracic cage fractures especially rib fractures were more likely to present a common complication of CPR, and are mostly not avoidable. The number of fatal injuries due to chest compressions during cardiopulmonary resuscitation increased as the compression depth exceeded $6 \mathrm{~cm}$. and there is a positive correlation with the long duration of CPR. The risk of mortality may be related to age, gender and duration of CPR. In the future, prospective multicenter studies with a larger number of individuals are needed in order to focus on CPR- related complications.

\section{References}

Beydilli H, Balcı Y, Iş̧k S et al., (2015): Resuscitation complications encountered in forensic autopsy cases performed in Muğla province. Ulus Travma Acil Cerrahi Derg, November. Vol. 21, No. 6 463-468.

Black CJ, Busuttil A and Robertson C (2004): Chest wall injuries following cardiopulmonary resuscitation. Resuscitation. 63(3):339-343.

Boz B, Erdur B, Acar K et al., (2008): Frequency of skeletal chest injuries associated with cardiopulmonary resuscitation: forensic autopsy. Ulus Travma Acil Cerrahi Derg; 14:216-20.

Buschmann CT and Tsokos M (2009): Frequent and rare complications of resuscitation attempts Intensive Care Med 35:397-404

Deliligka A, Voultsos p, Garyfallos A et al., (2016): Cardiopulmonary resuscitation-related complications. An essential approach to rescuer's liability in Greece. Rom J Leg Med. (24) 273-276.

Guzel S, Balci Y and Cetin G (2013): Tu“rk ceza kanununda tanimlanan yaralama suclarinin adli tip acisindan degerlendirilmesi. Ankara, Turkey:
Council of Forensic Medicine. Forensic Medicine Institute Publisher.

Hashimoto Y, Moriya F and Furumiya J (2007): Forensic aspects of complications resulting from cardiopulmonary resuscitation. Legal Medicine (9): 94-99.

Hellevuo H, Sainio M, Nevalainen R et al., (2013): Deeper chest compression - More complications for cardiac arrest patients? Resuscitation (84) 760-765.

Hokea RS and Chamberlaina D (2004): Skeletal chest injuries secondary to cardiopulmonary resuscitation. Resuscitation (63) 327-338

Kaldirim U, Toygar M, Karbeyaz K et al., (2016): Complications of cardiopulmonary resuscitation in non-traumatic cases and factors affecting complications. Egyptian Journal of Forensic Sciences (6), 270-274.

Kim EY, Yang HJ, Sung YM et al., (2011): Multidetector CT findings of skeletal chest injuries secondary to cardiopulmonary resuscitation. Resuscitation; 82:1285-8.

Kim MJ, Park YS, Kim SW et al., (2013): Chest injury following cardiopulmonary resuscitation: a prospective computed tomography evaluation. Resuscitation. 84:361-364.

Lederer W, Mair D, Rabi W et al., (2004): Frequency of rib and sternum fractures associated with out-ofhospital cardiopulmonary resuscitation is underestimated by conventional chest X-ray. Resuscitation. 60(2):157-162.

Machii M, Inaba H, Nakae H et al., (2000): Cardiac rupture by penetration of fractured sternum: a rare complication of cardiopulmonary resuscitation. Resuscitation; 43: 151-153.

Olds K, Byard RW and Langlois NE (2015): Injuries associated with resuscitation e An overview Journal of Forensic and Legal Medicine (33): 39-43.

Özer E, Şam B, Tokdemir MB et al., (2010): Complications of cardiopulmonary resuscitation. Cumhuriyet Med. J; 32: 315-322.

Rilana Baumeister AN, UlrikeHeld B, MichaelJThali A et al., (2015): Forensic imaging findings by post-mortem computed tomography after manual versus mechanical chest compression. Journal of Forensic Radiology and Imaging. 167-173.

Rudinskáa LI, Hejnac P, Ihnátd P H et al., (2016): Intrathoracic injuries associated with cardiopulmonary resuscitation - Frequent and serious. Resuscitation (103) 66-70.

Ryan MP, Young SJ and Wells DL (2003): Do resuscitation attempts in children who die, cause injury? Emerg. Med J (20):10-12.

Smekal D, Lindgren E, Sandler H et al., (2014): CPRrelated injuries after manual or mechanical chest compressions with the LUCAS $^{\text {TM }}$ device: a 
multi-center study of victims after unsuccessful resuscitation. Resuscitation. 85(12):1708-1712.

Sommers MS. (1991): Potential for injury: trauma after cardiopulmonary resuscitation. Heart Lung; 20:287-93.
Travers AH, Rea TD, Bobrow BJ et al., (2010): CPR overview 2010 American heart association guidelines for cardiopulmonary resuscitation and emergency cardio-vascular care. Circulation. (122): S676-845.

\section{الملخصص العربي}

\section{الجوانب الطبية الشرعية للمضاعفات المتملة المهددة للحياة الناجمة عن الإنعاش القلبي الرئوي المغلق في المرضى الغير مصابين}

\section{سحر محمد مصطقى}

يعد الإنعاث القلبي الرئوي إجراءء لإنقاذ الحياة والذي يمكنه أن يسبب أيضاً العديد من الإصابات التي قهد حياة المرضى. بما أن المضاعفات

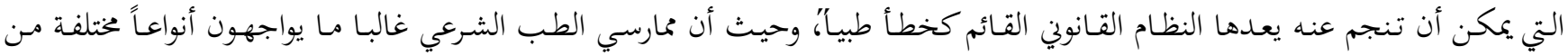
الإصابات قد تكون ذات صلة بالإنعاث القلبي الرئوي أثناء القيام بتقرير الصفة التشريحية للجثث، لذا يجب أن يكونوا قادرين على التمييز بين الإصابات الناجمة عن الإنعاش القلبي الرئوي وتلك التي تنتج عن عوامل أخرى. وكان الهدف من هذه الده الدراسة هو تحليل نتائج تقارير الصفة التشريحية للمرضى الذين تلقوا الإنعاث القبي الرئوي لتحديد معدل إنتشار هذه الإصابات و التي قد تمدد الحياة وكذلك تحديد العوامل المحتملة

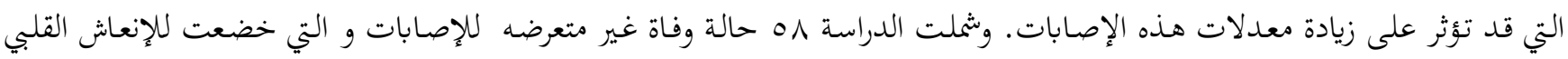
الرئوي وقد تم تحديد الإصابات النابحة عنها على أساس نتائج تقارير كلاً من الأشعة السينية و المقطعية. وقد خلصت النتائج إلى أن تقنية

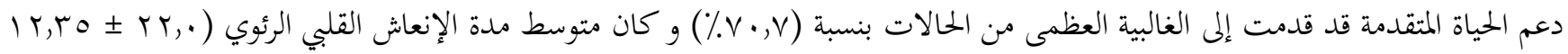

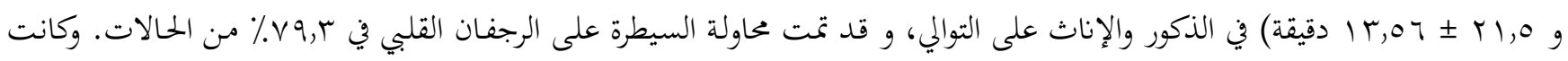

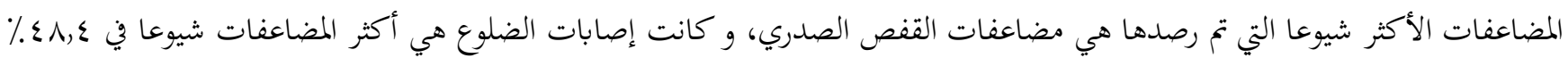

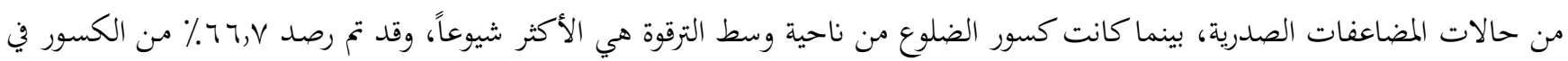
عظمة القص عند مستوى الضلع الثالث وقد كان الذكور أكثر عرضة لكسور الضلوع وعظمة القص أكثر من النساء. ووجد أن عوامل العمر والجنس ومدة الإنعاش القلبي الرئوي لها تأثيرعلى زيادة خطر الإصابة الناجمة عن الإنعاش القبي الرئوي والتي قد تمد الحياة. وقد لوحظ إزدياد خطر هده الإصابة خاصة"عندما يتجاوز عمق الضغط على الصدر I سم. و كذلك عندما تتجاوز مدة الإنعاش القبي الرئوي • ب دقيقة. وقد خلصت هذه الدراسة إلى أن مضاعفات الإنعاش القبي الرئوي قد تقلل من فرص المريض في الحياة، ويمكن كذلك أن تسبب الوفاة. و و توصي الدراسة بالقيام بدراسات مفصلة للصفة التشريحية تخص الإصابات الناجمة عن الإنعاش القلبي الرئوي المهادة للحياة في محاولة لمنعها. 